\title{
Differential Effects of the Complement Peptides, C5a and C5a des Arg on Human Basophil and Lung Mast Cell Histamine Release
}

\author{
Edward S. Schulman, " Thomas J. Post, * Peter M. Henson, ${ }^{\ddagger}$ and Patricia C. Giclas \\ Department of Medicine, Jefferson Medical College,* Philadelphia, Pennsylvania 19107; and the Departments of Pediatrics and \\ Medicine, University of Colorado Medical Center, National Jewish Center for Immunology and Respiratory Medicine, ${ }^{\ddagger}$ \\ Denver, Colorado 80206
}

\section{Abstract}

The ability of purified anaphylatoxins to induce human lung mast cell mediator release was investigated. In eight anti-IgE responsive (histamine release $=22 \pm 5 \%$, mean \pm SEM) mast cell preparations of 1-96\% purity, C5a and C5a des Arg (0.55 $\mathrm{pg} / \mathrm{ml}$ to $55 \mu \mathrm{g} / \mathrm{ml}$ ), failed to elicit or potentiate histamine release; lung fragments were similarly unresponsive. The related peptide $\mathrm{C} 3 \mathrm{a}$ was also inactive. All anaphylatoxins failed to induce mast cell leukotriene $\mathrm{C}_{4}\left(\mathrm{LTC}_{4}\right)$ and prostaglandin $\mathrm{D}_{2}$ $\left(\mathrm{PGD}_{2}\right)$ release. $\mathrm{LTC}_{4}$ release was also negligible from basophils where C5a was a potent histamine release stimulus. Supernatants from C5a-challenged mast cells remained fully active on basophils, excluding carboxypeptidase inactivation of C5a as an explanation for the lung mast cell results. In contrast to lung, skin mast cells were C5a-responsive (histamine release $=8 \pm 1 \%$, at $55 \mu \mathrm{g} / \mathrm{ml}, n=2)$. We conclude that C5a, though devoid of activity on the human lung mast cell, is a human basophil and skin mast cell secretogogue. These findings demonstrate significant organ-specific heterogeneity in mast cell responsiveness.

\section{Introduction}

The biologically active fragment of the fifth complement component, C5a, is capable of triggering release reactions from diverse inflammatory cell types. These reactions result in increased vascular permeability, smooth muscle contraction, and an influx of inflammatory cells, especially neutrophils, that may cause end organ damage (1). A major target organ for these protean effects is the lung (2). Pathologically, dose-dependent lung destruction is characterized by the closure of arterioles and small airways, and disruption of the alveolar network (2). In rodents and rabbits, direct intrabronchial instillation of anaphylatoxins causes severe lung injury and acute respiratory distress $(3,4)$. Removal of the COOH-terminal arginine of human $\mathrm{C5a}$ by serum carboxypeptidase- $\mathrm{N}$ results in formation of C5a des Arg, nullifying its anaphylatoxin properties and diminishing its inflammatory effects $(5,6)$.

Anaphylatoxins have long been suspected of playing a significant role in allergic disease. The effects of $\mathrm{C5a}$ as an in-

Address reprint requests to Dr. Schulman, Room 621 Bobst Building, Hahnemann Medical College, Broad and Vine Street, Philadelphia, PA 19102.

Received for publication 25 July 1986 and in revised form 26 October 1987.

J. Clin. Invest.

(c) The American Society for Clinical Investigation, Inc.

0021-9738/88/03/0918/06 \$2.00

Volume 81, March 1988, 918-923 ducer of histamine release from human basophils (7-9) and rat mast cells (10) have been well characterized. Studies to date characterizing the effects of anaphylatoxins in allergic lung reactions have been performed using animal models (11-14), and significant interspecies differences have been noted (11). This study was undertaken to examine the ability of purified human C5a and C5a des Arg to directly induce histamine release from purified human lung mast cells, the central cell type of human asthma $(15,16)$. We utilized highly purified, well characterized lipopolysaccharide-free $(<10 \mathrm{ng} / \mathrm{ml})$ preparations of $\mathrm{C5a}$ and $\mathrm{C5a}$ des Arg to avoid misleading results from minor contaminants (17).

We report that purified C5a, though a potent human basophil secretagogue and a weak human skin mast cell secretagogue, is devoid of direct anaphylatoxin activity for the human lung mast cell.

\section{Methods}

Materials. The following were purchased: elastase Type I, chymopapain (Sigma Chemical Co., St. Louis, MO); collagenase (Worthington Biochemicals, Freehold, NJ); DNase, pronase (Calbiochem-Behring Corp., San Diego, CA); gelatin (Difco Laboratories, Detroit, MI). Rabbit anti-human IgE antibody was generously provided by Dr. Terumo Ishizaka, (Johns Hopkins University, Baltimore, MD). Leukotriene $\mathrm{C}_{4}\left(\mathrm{LTC}_{4}\right)^{1}$ standard and the antisera for the leukotriene $\mathrm{C}_{4}$ radioimmunoassay were provided by $D r$. Anthony Ford-Hutchinson, (Merck-Frosst Inc., Montreal, Canada). The prostaglandin $\mathrm{D}_{2}$ standard was purchased from Cayman Chemicals (Denver, CO); the antisera for the radioimmunoassay was provided by Dr. Shuh Naramiya (Kyoto University, Kyoto, Japan). Tritiated standards were obtained from New England Nuclear (Boston, MA).

Buffers. Lung fragment washes were performed in Tyrode's buffer that contained (g/liter); $\mathrm{NaCl}, 8.0 ; \mathrm{KCl}, 0.2 ; \mathrm{NaH}_{2} \mathrm{PO}_{4}, 0.05$, and glucose, 1.0. The buffer was titrated to $\mathrm{pH} 7.2$ by the addition of $\mathrm{NaHCO}_{3}$. Mast cell isolation and elutriation were performed in TGMD: Tyrode's buffer with gelatin ( $1.0 \mathrm{~g} /$ liter $)$, magnesium $(0.25$ $\mathrm{g} /$ liter; $1 \mathrm{mM}$ ), and DNase (0.01 g/liter) added. Basophil washes were performed in a Pipes-albumin (PA) buffer that contained: Pipes 7.6 $\mathrm{g} /$ liter; $\mathrm{NaCl}, 6.4 \mathrm{~g}$ /liter; $\mathrm{KCl}, 0.37 \mathrm{~g}$ /liter; $\mathrm{NaOH} 10 \mathrm{~N}, 4.2 \mathrm{ml} /$ liter; and $3 \times$ recrystallized human serum albumin, $0.03 \mathrm{~g} /$ liter. TGMDCM or PAGCM were the Tyrode's or PA buffers containing: $\mathrm{CaCl}_{\mathbf{2}} \cdot \mathbf{2} \mathrm{H}_{\mathbf{2}} \mathrm{O}$, $0.14 \mathrm{~g} /$ liter ( $1 \mathrm{mM}$ ); $\mathrm{MgCl}_{2} \cdot 6 \mathrm{H}_{2} \mathrm{O}, 0.2 \mathrm{~g} /$ liter $(1 \mathrm{mM})$; and glucose, 1.0 g/liter.

Leukocytes. After obtaining informed consent, venous blood was drawn from patients undergoing lung resection, or from atopic and nonatopic normal volunteers, then sedimented over Dextran 75-

1. Abbreviations used in this paper: C5a, the fragment of the fifth component of complement with anaphylatoxin activity; C5a des Arg, the fragment formed by removal of the $\mathrm{COOH}$-terminal arginine from C5a; LTC $_{4}$, leukotriene $\mathrm{C}_{4}$; PA, Pipes-albumin; PAF, platelet-activating factor; PAGCM, Pipes-albumin buffer containing gelatin, magnesium, and DNase; TGMD, Tyrode's buffer containing gelatin, magnesium, and DNase. 
EDTA (2.5 mM) for $1 \mathrm{~h}$ (18). Mixed leukocytes, usually containing $\leq 1.0 \%$ basophils, were washed thrice at $22^{\circ} \mathrm{C}$ in PA buffer.

Human lung mast cells. Mast cells were dispersed from human lung by methods previously reported $(19,20)$. Briefly, lung specimens obtained at thorocotomy for bronchogenic carcinoma were finely minced and extensively washed in divalent cation-free Tyrode's buffer. Fragments were briefly incubated twice in a mixture of pronase $(2 \mathrm{mg} / \mathrm{ml})$ and chymopapain $(0.5 \mathrm{mg} / \mathrm{ml})$. Freed cells were harvested through Nytex nylon cloth ( $150 \mu \mathrm{m}$ pore size). Residual fragments were further exposed to a mixture of collagenase $(1 \mathrm{mg} / \mathrm{ml})$ and porcine elastase $(10$ $\mathrm{U} / \mathrm{ml}$ ). All incubations and washes were performed at $22^{\circ} \mathrm{C}$; all recovered cells were immediately washed three times in large volumes of TGMD. Mast cell purities in these human lung cell suspensions ranged from 1 to $8 \%$ as determined by alcian blue staining (21). In experiments requiring purified lung mast cells or designed to examine mast cell subpopulations separated on the basis of diameter, cell suspensions were subjected to counter-current elutriation, using previously reported methods (20). Mast cells were purified (80-96\%) by flotation of enriched elutriation fractions through a discontinuous Percoll gradient (22).

Chopped human lung. The methods used to prepare and challenge human lung fragments have been reported in detail previously $(23,24)$. Briefly, subpleural parenchymal strips well separated from tumor were carefully dissected free of visible blood vessels and pleura. Cut fragments of $10-20 \mathrm{mg}$ each were washed six times in large volumes of Tyrode's buffer at $22^{\circ} \mathrm{C}$; fragments were challenged within $1-2 \mathrm{~h}$ of lung resection.

Human skin mast cells. Mast cells were dispersed from human foreskin by the methods of Benyon et al. (25). Briefly, skin fragments were finely minced and extensively washed in divalent cation-free Tyrode's buffer. Fragments were exposed to collagenase $(1.5 \mathrm{mg} / \mathrm{ml})$ and hyaluronidase $(0.5 \mathrm{mg} / \mathrm{ml})$. Dispersed cells were harvested through Nytex cloth and washed with RPMI/1.5\% fetal calf serum. Mast cell purities ranged from 1 to $3 \%$.

C5a, C3a, and C5a des Arg. C5a and C3a were purified from human serum as previously described (17). The C5a preparation used for these experiments contained $55 \mu \mathrm{g}$ protein $/ \mathrm{ml}$ and had $1 \times 10^{6}$ $\mathrm{U} / \mathrm{ml}$ of myeloperoxidase-releasing activity when tested with cytochalasin B-treated human neutrophils (26). Both the C3a and C5a were positive when tested for their ability to cause increased vascular permeability in guinea pig skin (5). C5a des Arg was prepared from C5a by treatment with insolubilized carboxypeptidase B in PBS at pH 7.5 at $22^{\circ} \mathrm{C}$ for $20 \mathrm{~h}$. After treatment with carboxypeptidase, a shift in the $R_{\mathrm{f}}$ from 0.49 to 0.40 was observed on acid $6 \%$ polyacrylamide gel electrophoresis, indicating conversion to the $\mathrm{C} 5 \mathrm{a}$ des Arg form. All preparations were stored at $-20^{\circ} \mathrm{C}$ until thawed for use. Dilutions were prepared in either PAGCM or TGMDCM.

Histamine release assay. Washed leukocytes $\left(40 \times 10^{3}\right.$ basophils/ tube) or mast cells (10-50 $\times 10^{3} /$ tube) were challenged in duplicate with buffer, anti-IgE, C5a or C5a des Arg, or C3a at either 22 or $37^{\circ} \mathrm{C}$ in PAGCM or TGMDCM. The concentrations of C5a and C3a used covered a physiologic range based on the maximum amounts of each that could be generated from activation of serum complement: C3 1 $\mathrm{mg} / \mathrm{ml}$, C3a from $100 \%$ C3 conversion $60 \mathrm{mg} / \mathrm{ml}$; C5 50-100 g/ml, C5a from $100 \%$ conversion $3-6 \mathrm{~g} / \mathrm{ml}$. In chopped lung studies, six $10-20 \mathrm{mg}$ fragments in $0.5-1.0 \mathrm{ml}$ were similarly challenged in TGMDCM. After $45 \mathrm{~min}$ for basophil incubations $(7,8,18)$ or $20 \mathrm{~min}$ for mast cell incubations (19), cells were rapidly pelleted and supernatants removed for analysis of mediator release. In chopped lung studies, one-half of the supernatant was removed for histamine, LTC $_{4}$ and $\mathrm{PGD}_{2}$ analysis and the volume was replaced with $4 \%$ perchloric acid. In the experiments indicated, basophils, mast cells, or chopped lung preparations were pretreated with cytochalasin $B(1 \mu \mathrm{g} / \mathrm{ml})$ for $5 \mathrm{~min}$ before addition of C5a or C5a des Arg. Histamine released into the supernatant was expressed as the net histamine released divided by the total histamine content $\times 100 \%$. The total cellular histamine content was determined by cell lysis in $2 \%$ perchloric acid. The total histamine content of lung fragments was determined by boiling the perchloric acid-treated fragments for $10 \mathrm{~min}$. Spontaneous histamine release was always $<5 \%$ of cellular histamine. Histamine measurements were performed by the automated spectrofluorometric method of Technicon Co. (Tarrytown, NY). Variation between replicates was consistently $<5 \%$. All experiments were performed on at least three individual basophil and mast cell donors.

$L T C_{4} . \mathrm{LTC}_{4}$ measurements were performed on unextracted mast cell or lung fragment supernatants using the radioimmunoassay previously described (27). Though the antibody shows $50 \%$ cross-reactivity with leukotriene $\mathrm{D}_{4}\left(\mathrm{LTD}_{4}\right)$, the $\mathrm{LTC}_{4}$ generated by isolated mast cells under these experimental conditions is not further metabolized (28). The assay is sensitive to $0.1 \mathrm{ng} / \mathrm{ml}$ of $\mathrm{LTC}_{4}$.

Prostaglandin $\mathrm{D}_{2}\left(P G D_{2}\right)$. $\mathrm{PGD}_{2}$ measurements were similarly performed on unextracted supernatants. The antibody has $<0.5 \%$ crossreactivity with $\mathrm{PGF}_{2 \alpha} \mathrm{PGE}, \mathrm{TxB}_{2}$ and 6-keto-PGF ${ }_{1 \alpha}(29)$. This assay is sensitive to $0.1 \mathrm{ng} / \mathrm{ml}$ of $\mathrm{PGD}_{2}$.

Statistics. Data were expressed as the mean \pm SEM in the text and figures. Multiple comparisons were performed using an analysis of variance (ANOVA) and a Newman-Keul test. Significance in all tests was taken at $P<0.05$.

\section{Results}

Anaphylatoxin challenge of human lung mast cells. Mast cells from eight different lungs were challenged with release stimuli (Fig. 1). In the first four experiments, mast cells at 80, 92, 93, and $96 \%$ purity were challenged for $20 \mathrm{~min}$ at $37^{\circ} \mathrm{C}$ with varying doses of anti-IgE $(0.1-30 \mu \mathrm{g} / \mathrm{ml})$ and C5a and C5a des Arg anaphylatoxins $(0.55 \mathrm{pg} / \mathrm{ml}$ to $55 \mu \mathrm{g} / \mathrm{ml})$. Anaphylatoxin, but not anti-IgE, challenges were performed in the presence of cytochalasin B $(1 \mu \mathrm{g} / \mathrm{ml})$. In all four experiments, purified mast cells responded to anti-IgE (peak release of $23 \pm 5 \%$, mean \pm SEM) but failed to respond to anaphylatoxins at any dose. In four additional human lung experiments we examined the possibility that mast cells needed "helper" cell types to respond. Lung cell suspensions containing 1, 4, 6, and $8 \%$ mast cells were similarly challenged. Again, anaphylatoxin failed to elicit histamine release, while anti-IgE proved an effective stimulus (peak release $=21 \pm 7 \%$ ).

Because of a prior report showing a loss of basophil responsiveness to complement if cells were exposed to $37^{\circ} \mathrm{C}$ before challenge (7), lung cells were constantly kept at $25^{\circ} \mathrm{C}$ until

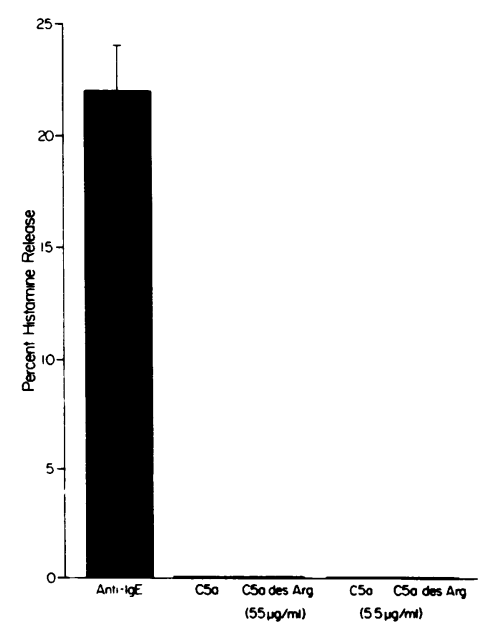

Figure 1. Effects of antiIgE, C5a and C5a des Arg on mast cells derived from eight human lungs. Mast cells of $1-96 \%$ purity were incubated with stimuli for $20 \mathrm{~min}$ at $37^{\circ} \mathrm{C}$ then supernatants were analyzed for histamine release. Mast cells challenged with $\mathrm{C5a}$ and C5a des Arg but not with anti-IgE were preincubated with cytochalasin B ( $1 \mu \mathrm{g} / \mathrm{ml}$ ) for $5 \mathrm{~min}$ before challenge. Because the complement results from the four lung suspension and four purified mast cell

experiments were identical they were combined above. Anti-IgE results represent the peak histamine release response (mean \pm SEM) from dose-response curves. 
challenge in these latter four experiments. The same lung cell suspensions challenged with anaphylatoxins at $25^{\circ} \mathrm{C}$ instead of $37^{\circ} \mathrm{C}$ also failed to respond.

Despite the failure to exert a direct mast cell release effect, we investigated the potential for anaphylatoxins to potentiate an anti-IgE challenge in the absence and presence of cytochalasin B $(1 \mu \mathrm{g} / \mathrm{ml})$. As shown in Fig. 2, no enhancement of anti-IgE release was observed. C5a and C5a des Arg also failed to induce mast cell histamine release in buffer containing $44 \%$ deuterium oxide $\left(\mathrm{D}_{2} \mathrm{O}\right)$, an enhancer of IgE-mediated histamine release (results not shown).

Observations by Lepow et al. (30) and Wuepper et al. (31) suggested that the anaphylatoxin $\mathrm{C} 3 \mathrm{a}$ functioned as a human mast cell secretagogue. Consistent with this were studies of rat peritoneal mast cells demonstrating that $\mathrm{C} 3 \mathrm{a}$ was of equal potency to C5a as a histamine liberator (10). We, therefore, challenged three purified human lung mast cell preparations (76, 92, and 93\% purity) with dilutions of C3a and C3a des Arg (55 to $0.55 \mu \mathrm{g} / \mathrm{ml}$ ). Similar to C5a and C5a des Arg, these anaphylatoxins failed to elicit lung mast cell histamine release (antiIgE induced release $=20.8 \pm 11.6 \%$ ).

Challenge of mast cell subsets. Though receptors for C5a have been identified on the surface of almost all human neutrophils, only $50-60 \%$ of monocytes and $<10 \%$ of lymphocytes bear such receptors (32). Furthermore, the presence in leukocyte subpopulations of $\mathrm{C} 5 \mathrm{a}$ receptors may have func-

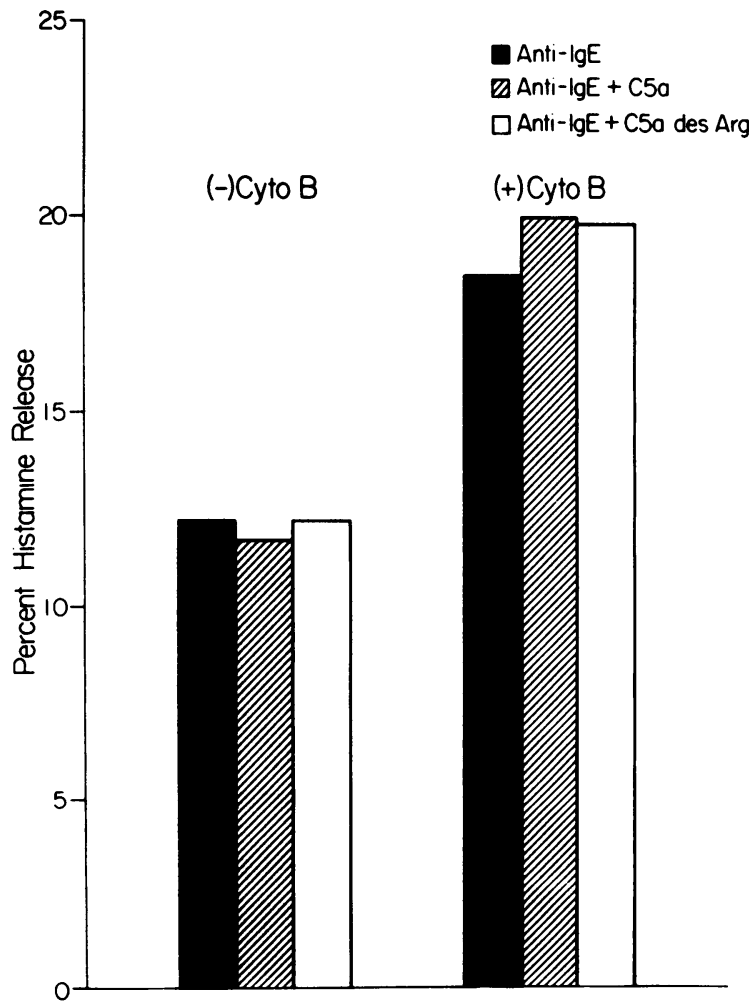

Figure 2. Effects of anaphylatoxins on anti-IgE-induced histamine release. Anaphylatoxins were added to suspension mast cells (80\% purity) preincubated for $5 \mathrm{~min}$ with cytochalasin B $(1 \mu \mathrm{g} / \mathrm{ml})$ or buffer. After $15 \mathrm{~min}$, anti-IgE $(10 \mu \mathrm{g} / \mathrm{ml})$ was added and the reaction allowed to proceed for an additional $20 \mathrm{~min}$ at $37^{\circ} \mathrm{C}$. No release enhancement was attributable to anaphylatoxins in the absence or presence of cytochalasin B. The experiment shown is one of three with similar results. tional correlates (32). We therefore examined functionally distinct human lung mast cell subpopulations, separated on the basis of their diameters by elutriation (20), for selective responses to release stimuli (Fig. 3). As we previously reported, most mast cells eluted in fractions representing cells of 12-15 $\mu \mathrm{m}$ in diameter (20); also, with increases in mast cell diameter, there was an increase in responsiveness to maximal anti-IgE (defined by dose-response curves). However, none of these distinct mast cell subpopulations were stimulated by anaphylatoxins at any concentration.

Anaphylatoxin challenge of fresh lung fragments. During the course of our experiments we examined whether the conditions of our mast cell isolation procedure were responsible for the observed failure of C5a and C5a des Arg to evoke human lung mast cell histamine release. We also questioned if the basophils of our lung donors were likewise unresponsive. In three patients undergoing lung resection, we examined the effects of anti-IgE, C5a, and C5a des Arg on lung fragments challenged within 1 to $2 \mathrm{~h}$ of resection, mast cells derived from their lung fragments, and their peripheral blood basophils obtained within $18 \mathrm{~h}$ of surgery (Table I). Anti-IgE challenge of lung fragments, mast cells and basophils elicited histamine release responses that were not significantly different (ANOVA) from each other. C5a challenge of each patient's basophils resulted in release responses that were significantly greater $(P<0.05)$ than the responses of their isolated mast cells and lung fragments. The donor basophil responses to C5a were not significantly different than their responses to anti-IgE. Challenge of lung fragments from subject 3 with C3a (final concentration $55 \mu \mathrm{g} / \mathrm{ml}$ ) also failed to evoke histamine release.

Examination of mast cells for carboxypeptidase activity. To further examine the differential effects of $\mathrm{C} 5 \mathrm{a}$ on basophils and lung mast cells, we considered the possibility that lung mast cells rapidly inactivated C5a by carboxypeptidase-like or oxidative activity. In three experiments, mast cells were challenged with buffer, C5a, or C5a des Arg for $20 \mathrm{~min}$ at $37^{\circ} \mathrm{C}$ (Fig. 4). Part of the mast cell supernatant was withdrawn for histamine release analysis and part was transferred to fresh basophils preincubated at $37^{\circ} \mathrm{C}$. Control basophils were chal-

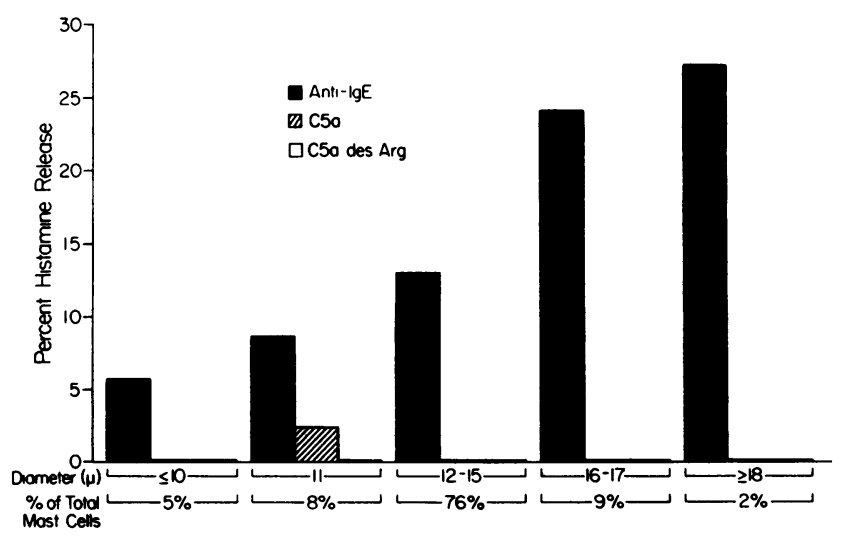

Figure 3. Failure of anaphylatoxins to stimulate diameter-separated human lung mast cell subpopulations. Shown are mast cell responses within subpopulations to maximal anti-IgE challenge, followed by C5a $(55 \mu \mathrm{g} / \mathrm{ml})$ and C5a des Arg $(55 \mu \mathrm{g} / \mathrm{ml})$. The minor release seen in response to C5a in the $11-\mu \mathrm{m}$ subset was not observed in two additional heterogeneity studies. Figures for mast cell diameters and percent of total mast cells are derived from reference 20 . 
Table I. Basophil, Mast Cell, and Lung Fragment Responsiveness to Release Stimuli ${ }^{* \ddagger}$ (Percent Histamine Release)

\begin{tabular}{|c|c|c|c|c|c|c|c|c|c|}
\hline \multirow[b]{2}{*}{ Subject No. } & \multicolumn{3}{|c|}{ Basophils } & \multicolumn{3}{|c|}{ Mast cells } & \multicolumn{3}{|c|}{ Lung fragments } \\
\hline & Anti-lgE & $\mathrm{C} 5 \mathrm{a}$ & C5a des Arg & Anti-IgE & C5a & C5a des Arg & Anti-IgE & C5a & C5a des Arg \\
\hline 1 & 8 & 11 & 2 & 10 & 1 & 0 & 7 & 0 & 0 \\
\hline 2 & 22 & 35 & 1 & 38 & 1 & 0 & 29 & 0 & 0 \\
\hline 3 & 5 & 14 & 3 & 15 & 0 & 0 & 16 & 1 & 1 \\
\hline
\end{tabular}

* Dose-response curves were performed for all stimuli, though only peak responses are shown. Peak basophil responses were achieved at antiIgE concentrations of $0.3-0.45 \mu \mathrm{g} / \mathrm{ml}$; anaphylatoxins at $0.55-22.5 \mu \mathrm{g} / \mathrm{ml}$. Peak mast cell anti-IgE responses were obtained at 3-10 $\mu \mathrm{g} / \mathrm{ml}$. The anaphylatoxin concentrations shown for mast cells challenges are $55 \mu \mathrm{g} / \mathrm{ml}$, but were no different for any concentration of C5a or C5a des Arg. Mast cell purities in the three subjects were 92,80 , and $93 \%$, respectively.

${ }^{\ddagger}$ Dispersed $(n=2)$ and minced $(n=1)$ foreskin fragments challenged with C5a at $55 \mu \mathrm{g} / \mathrm{ml}$ released 4-9\% of cellular histamine. These same preparations challenged with C5a des Arg at $55 \mu \mathrm{g} / \mathrm{ml}$ were unresponsive (see Results).

lenged with equivalent final concentrations of $\mathrm{C5a}$ and $\mathrm{C5a}$ des Arg not exposed to mast cells. As expected, mast cells were unresponsive to anaphylatoxins. Basophils directly challenged with $\mathrm{C} 5 \mathrm{a}(22.5 \mu \mathrm{g} / \mathrm{ml})$ demonstrated $27.2 \pm 16.1 \%$ histamine release; C5a that was first exposed to mast cells stimulated $27 \pm 14.3 \%$ histamine release. In addition, C5a mixed in a test tube with supernatant removed from buffer-challenged mast cells resulted in $26.1 \pm 16.4 \%$ histamine release. These histamine release values were not significantly different from each other.

$L T C_{4}$ and $P G D_{2}$. In two studies of purified mast cells, release of the non-preformed mast cell mediators, $\mathrm{LTC}_{4}$ and $\mathrm{PGD}_{2}$ were examined. Measurements of both mediators after buffer, C5a, C5a des Arg, and C3a challenges were below the levels of detection for the assays. Maximal anti-IgE challenges (histamine release $=20 \pm 6 \%$ ) induced LTC $_{4}$ release of $32.7 \pm 2.3 \mathrm{fg} /$ mast cell and $\mathrm{PGD}_{2}$ release of $34.7 \pm 19.2 \mathrm{fg} /$ mast cell. In three lung fragment studies, anaphylatoxin challenges

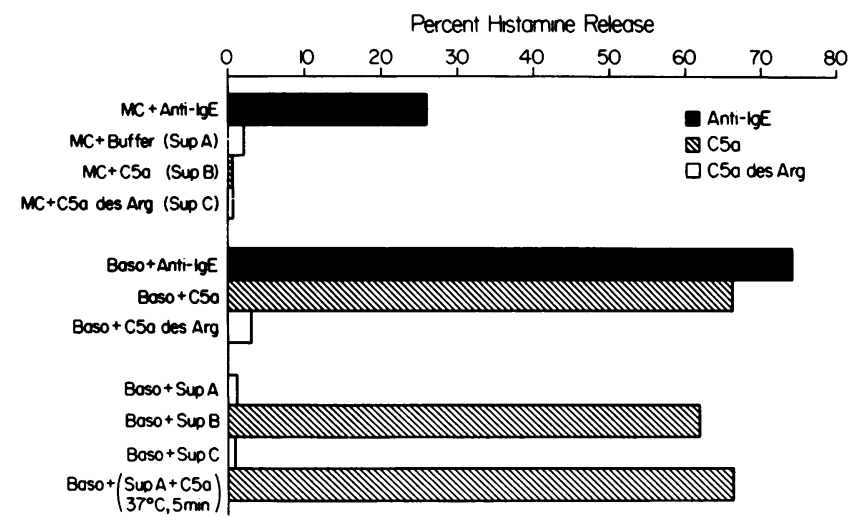

Figure 4. Effects of mast cells on activity of anaphylatoxins. Mast cells were incubated in buffer, anti-IgE $(3 \mu \mathrm{g} / \mathrm{ml}), \mathrm{C} 5 \mathrm{a}(55 \mu \mathrm{g} / \mathrm{ml})$ or C5a des Arg $(55 \mu \mathrm{g} / \mathrm{ml})$, in a final volume of $200 \mu \mathrm{l}$. After a 20-min incubation at $37^{\circ} \mathrm{C}$, cells were rapidly sedimented; $50 \mu l$ was then removed for histamine analysis and $100 \mu \mathrm{l}$ was transferred to basophils preincubated at $37^{\circ} \mathrm{C}$ in $100 \mu \mathrm{l}$ of buffer. Final anaphylatoxin concentration in all basophil challenges was $22.5 \mu \mathrm{g} / \mathrm{ml}$. Final anti-IgE concentration in basophil challenges was $0.3 \mu \mathrm{g} / \mathrm{ml}$. Supernatant $A$ (buffer and mast cells $\times 20 \mathrm{~min}, 37^{\circ} \mathrm{C}$ ) was removed and incubated with $\mathrm{C} 5 \mathrm{a}$ in a test tube at $37^{\circ} \mathrm{C}$ for $20 \mathrm{~min}$ then added to basophils. Activity was fully evident. The experiment is one of three with similar results. failed to induce $\mathrm{LTC}_{4}$ or $\mathrm{PGD}_{2}$ release. Anti-IgE challenge (histamine release $=17 \pm 5 \%$ ) resulted in $\mathrm{LTC}_{4}$ release of $6.1 \pm 3.3 \mathrm{ng} / \mathrm{g}$ wet wt and $\mathrm{PGD}_{2}$ release of $135 \pm 3.5 \mathrm{ng} / \mathrm{g}$ wet wt of lung. Interestingly, even though the anaphylatoxins are potent stimulators of basophil histamine release, they failed to activate pathways of $\mathrm{LTC}_{4}$ generation. After challenges of three highly responsive basophil donors with C5a (maximum histamine release $=48 \pm 4 \%$ at $5.5 \mu \mathrm{g} / \mathrm{ml}, \mathrm{EC}_{50}=0.9 \mu \mathrm{g} / \mathrm{ml}$ ) and with $\mathrm{C5a}$ des $\mathrm{Arg}$ (maximum histamine release $=26 \pm 4 \%$ at $55 \mu \mathrm{g} / \mathrm{ml}, \mathrm{EC}_{50}=10.7 \mu \mathrm{g} / \mathrm{ml}$ ) $\mathrm{LTC}_{4}$ was undetectable in the supernatants. This contrasts with anti-IgE-induced $(0.3$ $\mu \mathrm{g} / \mathrm{ml}$ ) release: histamine release of $57 \pm 6.0 \%$ was coupled with appreciable $\mathrm{LTC}_{4}$ release of $2.4 \pm 0.7 \mathrm{fg} /$ basophil.

Human skin mast cells. The impotence of C5a as a lung mast cell secretagogue contrasted strikingly with prior in vivo studies where injection of C5a into human skin produced wheal and flare responses and resulted in mast cell degranulation as visualized both at the light and electron microscopic level $(33,34)$. To evaluate potential human organ-specific differences in reactivity, mast cells dispersed from human foreskin were challenged with C5a, C5a des Arg, and ionophore A23187 $(0.3 \mu \mathrm{g} / \mathrm{ml})$. In two experiments, C5a induced $8 \pm 1 \%$ histamine release at $55 \mu \mathrm{g} / \mathrm{ml}, 6 \pm 1 \%$ at $5.5 \mu \mathrm{g} / \mathrm{ml}$ and $0 \%$ at $0.55 \mu \mathrm{g} / \mathrm{ml}$. At the same concentrations, C5a des Arg failed to elicit release. Ionophore-induced release was $28 \pm 4 \%$. In a third experiment, minced skin fragments were challenged; C5a induced 4\% histamine release, C5a des Arg 0\% release and ionophore $6 \%$ histamine release. The limitations in specimen size did not allow for arachidonate metabolite measurements in the skin samples.

\section{Discussion}

A critical role for the anaphylatoxins C5a and C5a des Arg has been suggested in both immunologic and nonimmunologic lung disease (1-4, 11-14). In fact, the lung may serve as the major target organ for the effects of these mediators (11). Studies undertaken to identify the nature of the mediators released during anaphylatoxin-induced lung injury have found products derived from degranulated mast cells, the central cell type of allergic asthma $(11,12)$. These studies also emphasized the significant species differences among the specific activities of the anaphylatoxins themselves. For this reason, a study was undertaken to define the actions of purified human C5a and its 
putative physiologic form C5a des Arg, on human lung mast cells.

We conclude that, in contrast to animal mast cells and lung tissues, human lung mast cells and tissues fail to respond to purified human C5a and C5a des Arg, either directly or synergistically with an IgE-mediated stimulus. Furthermore, there is no evidence for inactivation of $\mathrm{C} 5 \mathrm{a}$ by any activity derived from mast cells: C5a exposed to mast cells is as active in inducing basophil histamine release as is our fresh C5a preparation. Conditions of the mast cell isolation cannot account for our results. Mast cells in suspension retain their capacity to respond to anti-IgE, a trigger whose release mechanism, like $\mathrm{C5a}$, is also dependent on cell surface receptors. Human lung fragments, challenged within 1 to $2 \mathrm{~h}$ of resection and never exposed to mast cell isolation conditions, likewise are entirely unresponsive to anaphylatoxins. Basophils from the same lung donors are quite responsive to anti-IgE and even more responsive to C5a, indicating that our mast cell "donors" are anaphylatoxin "responders."

Since prior studies implicated that small functional subsets of leukocytes can be defined based on C5a receptors (32), we examined functionally distinct subsets of human lung mast cells defined morphologically on the basis of their diameters (20). We felt that direct C5a challenge of quantitatively small subsets might magnify and define effects that are lost in whole lung fragments or in whole lung suspensions. Again, under these conditions, we failed to find a $\mathrm{C} 5 \mathrm{a}$ responder subset.

The failure of human lung mast cells to respond to C5a obviously contrasts with older human skin studies $(33,34)$. In those studies, injection of anaphylatoxins produced wheal and flare responses that were ascribed to cutaneous mast cell degranulation; reactions were partially inhibitable if skin sites were pretreated with an antihistamine $(33,34)$. One obvious explanation for these differences is that of organ-specific differences in mast cell type and function (lung vs. skin). Studies in rodents have clearly demonstrated marked differences in structure and function between mast cells in the peritonium (connective tissue mast cells) and gastrointestinal mucosa (mucosal mast cells) (35). Even within organs, (e.g., rat skin), there is histochemical evidence of two mast cell subtypes (36).

To test the hypothesis that C5a responsiveness was organ specific, we challenged both skin mast cell suspensions (two experiments) and minced fragments (one experiment) with C5a and C5a des Arg. In each instance, low level (4-9\%) histamine release resulted. This in vitro data is consistent with the intradermal injection studies. Since human skin reactivity to C5a (and C3a) are only partially inhibitable with antihistamines, it is possible that the observed wheal and flare responses are heavily dependent on the direct stimulation of cells other than mast cells. In fact, this has been shown in rabbits where the skin reactivity of intradermally administered C5a is independent of histamine release (37): the observed plasma exudation and edema appears to involve a synergism between complement fragments and vasodilator prostaglandins (e.g., $\mathrm{PGE}_{2}$ ) derived from non-mast cell sources (37). Another alternative explanation is that target cells (e.g., neutrophils), directly stimulated by $\mathrm{C} 5 \mathrm{a}$, may release their own vasoactive mediators and/or secondarily stimulate secretion of mast cell/basophil mediators. For example, C5a can stimulate neutrophil generation and release of the labile arachidonate intermediate leukotriene $\mathrm{A}_{4}$ (LTA $)$ (38); released LTA 4 may then be "remodelled" by mast cells and other cells to generate bioactive arachi- donate products (38). Though this hypothesis is attractive, our results cast doubt that the C5a response is dependent on neutrophils. C5a challenges of whole lung suspension (5\% neutrophils) and of mixed leukocyte preparations (50-70\% neutrophils) failed to stimulate $\mathrm{LTC}_{4}$ release. This result was particularly surprising in the mixed leukocyte preparation, where C5a proved as effective a histamine liberator as anti-IgE, but was an insufficient signal to activate basophil arachidonate metabolism. Platelet-activating factor (PAF), a mediator capable of contributing to wheal and flare reactions, is directly released from neutrophils following anaphylatoxin challenge $(39,40)$, and may prove an important contributor to the skin responses.

In conclusion, purified $\mathrm{C} 5 \mathrm{a}$ is a potent stimulant of the circulating basophil, a much weaker stimulant of the human cutaneous mast cell, and is devoid of activity on the human lung mast cell. These results point to a major difference in the biology of these related cell types (16). Our studies also suggest that significant differences exist in responsiveness to complement fragments among lung mast cells of human and animal origins.

\section{Acknowledgments}

The writers thank Drs. Benjamin Bachrach, Hong Choi, Herbert Cohn, Harry S. Cooper, John Decker, Domonic DeLaurentis, Charles Fineberg, Robert McCairns, Melvin J. Moses, Arthur Patchefsky, Francis E. Rosato, and Henry Stofman for providing lung specimens, Dr. Benjamin Cheyen for skin specimens, and Dr. James E. Fish and Dr. Stephen P. Peters for reviewing the manuscript.

Supported by grants AI-20634, HL-27353, and AI-17286 from the National Institutes of Health.

\section{References}

1. Hugli, T. E. 1984. Structure and function of the anaphylatoxins. Springer Semin. Immunopathol. 7:193-219.

2. Huey, R., C. M. Bloor, M. S. Kawahara, and T. E. Hugli. 1983. Potentiation of the anaphylatoxins in vivo using an inhibitor of serum carboxypeptidase N (SCPN). I. Lethality and effects on pulmonary tissue. Am. J. Pathol. 112:48-60.

3. Shaw, J. O., P. M. Henson, and R. O. Webster. 1980. Lung inflammation induced by complement-derived chemotatic fragments in the alveolus. Lab. Invest. 42:547-558.

4. Kreutzer, D. L., U. Desai, W. Orr, H. Showell, and P. A. Ward. 1979. Induction of acute inflammatory reactions in lung following intrapulmonary instillation of preformed chemotactic peptides and purified complement components. Chest. 75:259-264.

5. Cochrane, C. G., and H. J. Muller-Eberhard. 1968. The derivation of two distinct anaphylatoxin activities from the third and fifth components of human complement. J. Exp. Med. 127:371-386.

6. Gerard, C., and T. E. Hugli. 1981. Identification of the classical anaphylatoxin as C5a des Arg: Evidence of a modulator role for the oligosaccharide unit in human C5a. Proc. Nat. Acad. Sci. USA. 78:1833-1837.

7. Siraganian, R. P., and W. A. Hook. 1976. Complement-induced histamine release from human basophils. II. Mechanism of the histamine release reaction. J. Immunol. 116:639-646.

8. Grant, J. A., L. Settle, E. B. Whorton, and E. Dupree. Complement-mediated release of histamine from human basophils. II. Biochemical characterization of the reaction. J. Immunol. 117:450-456.

9. Farnam, J., J. A. Grant, M. A. Lett-Brown, C. Hunt, D. O. Thueson, and P. C. Giclas. 1985. Complement and IgE-mediated release of histamine from basophils in vitro. V. Differential effects of drugs modulating arachidonic acid metabolism. J. Immunol. 134:541-547. 
10. Johnson, A. R., T. E. Hugli, and H. J. Muller-Eberhard. 1975. Release of histamine from rat mast cells by the complement peptides C3a and C5a. Immunology. 28:1067-1080.

11. Hugli, T. E. 1983. Actions of anaphylatoxins on pulmonary tissues. In Skandia International Symposia: Theoretical and clinical aspects of allergic diseases. Almqvist and Wiksell International, Stockholm, Sweden. 197-211.

12. Stimler, N. P., M. K. Bach, C. M. Bloor, and T. E. Hugli. 1982. Release of leukotrienes from guinea pig lung stimulated by $\mathrm{C} 5 \mathrm{a}$ des Arg anaphylatoxin. J. Immunol. 128:2247-2252.

13. Stimler, N. P., W. E. Brocklehurst, T. E. Hugli, and C. M. Bloor. 1981. Anaphylatoxin mediated contraction of guinea pig lung strips: a non-histamine tissue response. J. Immunol. 126:2258-2261.

14. Regal, J. F., A. Y. Eastman, and R. J. Pickering. 1980. C5a induced tracheal contraction: a histamine independent mechanism. $J$. Immunol. 124:2876-2878.

15. Austen, K. F., and R. P. Orange. 1975. Bronchial asthma: The possible role of the chemical mediators of immediate hypersensitivity in the pathogenesis of subacute chronic disease. Am. Rev. Respir. Dis. 112:423-436.

16. Schulman, E. S., D. W. MacGlashan, R. P. Schleimer, S. P. Peters, G. K. Adams III, H. H. Newball, and L. M. Lichtenstein. 1983. Purified human basophils and mast cells: current concepts of mediator release. Eur. J. Respir. Dis. 64:53-61.

17. Webster, R. O., S. R. Hong, R. B. Johnston Jr., and P. M. Henson. 1980. Biological effects of the human complement fragments C5a and C5a des Arg on neutrophil function. Immunopharmacology. 2:201-219.

18. Lichtenstein, L. M., and A. G. Osler. 1964. Studies on the mechanisms of hypersensitivity phenomena. IX. histamine release from human leukocytes by ragweed pollen antigen. J. Exp. Med. 120:507-530.

19. Schulman, E. S., D. W. MacGlashan, S. P. Peters, R. P. Schleimer, H. H. Newball, and L. M. Lichtenstein. 1982. Human lung mast cells. Purification and characterization. J. Immunol. 129:26622667.

20. Schulman, E. S., A. Kagey-Sobotka, D. W. MacGlashan, N. F. Adkinson, Jr., S. P. Peters, R. P. Schleimer, and L. M. Lichtenstein. 1983. Heterogeneity of human mast cells. J. Immunol. 131:19361941.

21. Gilbert, H. S., and L. Ornstein. 1975. Basophil counting with a new staining method using alcian blue. Blood. 46:279-285.

22. Ishizaka, T., D. H. Conrad, E. S. Schulman, A. R. Sterk, and K. Ishizaka. 1983. Biochemical analysis of initial triggering events of IgE mediated histamine release from human lung mast cells. J. Immunol. 130:2357-2362.

23. Schulman, E. S., H. H. Newball, L. M. Demers, F. A. Fitzpatrick, and N. F. Adkinson, Jr. 1981. Anaphylactic release of thromboxane $A_{2}$, prostaglandin $D_{2}$ and prostacyclin from human lung parenchyma. Am. Rev. Respir. Dis. 124:402-406.

24. Schulman, E. S., N. F. Adkinson, Jr., and H. H. Newball. 1982. Cyclo-oxygenase metabolites in human lung anaphylaxis: airway vs. parenchyma. J. Appl. Physiol. 53:589-595.
25. Benyon, R. C., M. A. Lowman, and M. K. Church. 1987. Human skin mast cells: their dispersion, purification, and secretory characterization. J. Immunol. 138:861-867.

26. Webster, R. O., and P. M. Henson. 1978. Rapid micro-measurement of neutrophil exocytosis. Inflammation. 3:129-135.

27. MacGlashan, D. W., R. P. Schleimer, S. P. Peters, E. S. Schulman, G. K. Adams, III, H. H. Newball, and L. M. Lichtenstein. 1982. Generation of leukotrienes by purified human lung mast cells. J. Clin. Invest. 70:747-751.

28. Peters, S. P., D. W. MacGlashan, Jr., E. S. Schulman, R. P. Schleimer, E. C. Hayes, J. Rokach, N. F. Adkinson, Jr., and L. M. Lichtenstein. 1984. Arachidonic acid metabolism in purified human lung mast cells. J. Immunol. 132:1972-1979.

29. Narumiya, S., T. Ogorochi, K. Nakao, and O. Hayaishi. 1982. Prostaglandin $\mathrm{D}_{2}$ in rat brain, spinal cord and pituitary: basal level and regional distribution. Life Sci. 31:2093-2103.

30. Lepow, I. H., K. Wilms-Kretschmer, R. A. Patrick, and F. S. Rosen. 1970. Gross and ultrastructural observation on lesions produced by intradermal injection of human C3a in man. Am. J. Pathol. 61:13-20.

31. Wuepper, K. D., V. A. Bokisch, H. J. Muller-Eberhard, and R. B. Stoughton. 1972. Cutaneous responses to human C3a anaphlatoxin in man. Clin. Exp. Immunol. 11:13-20.

32. Van Epps, D. E., and D. E. Chenoweth. 1984. Analysis of the binding of fluorescent C5a and C3a to human peripheral blood leukocytes. J. Immunol. 132:2862-2867.

33. Vallota, E. H., and H. J. Muller-Eberhard. 1973. Formation of $\mathrm{C} 3 \mathrm{a}$ and C5a anaphylatoxins in whole human serum after inhibition of the anaphylatoxin inactivator. J. Exp. Med. 137:1109-1123.

34. Yancey, K. B., C. H. Hammer, L. Harvath, L. Renfer, M. M. Frank, and T. J. Lawley. 1985. Studies of human C5a as a mediator of inflammation in normal human skin. J. Clin. Invest. 75:486-495.

35. Bienenstock, J., A. D. Befus, F. L. Pearce, J. Denburg, and R. Goodacre. 1982. Mast cell heterogeneity: Derivation and function, with emphasis on the intestine. J. Allergy Clin. Immunol. 70:407-12.

36. Lampe, M., and J. A. Kiernan. 1977. Cytochemical variation of mast cells in the skin of the rat. Arch. Dermatol. Res. 258:69-80.

37. Williams, T. J., and P. J. Jose. 1981. Mediation of increased vascular permeability after complement activation. J. Exp. Med. 153:136-153.

38. Dahinden, C. A., R. M. Clancy, M. Gross, J. M. Chiller, and T. E. Hugli. 1985. Leukotriene $C_{4}$ production by murine mast cells: Evidence of a role for extracellular leukotriene $\mathrm{A}_{4}$. Proc. Natl. Acad. Sci. USA. 82:6632-6636.

39. Camussi, G., C. Tetta, F. Bussolino, F. Calgaris Cappio, R. Coda, C. Masera, and G. Segoloni. 1981. Mediators of immune-complex-induced aggregation of polymorphonuclear neutrophils. II. Platelet-activating factor as the effector substance of immune-induced aggregation. Int. Arch. Allergy Appl. Immunol. 64:25-41.

40. Pinckard, R. N., R. S. Farr, and D. J. Hanahan. 1979. Physicochemical and functional identity of rabbit platelet-activating factor (PAF) releases in vivo during IgE anaphylaxis with PAF released in vitro from IgE sensitized basophils. J. Immunol. 123:1847-1857. 